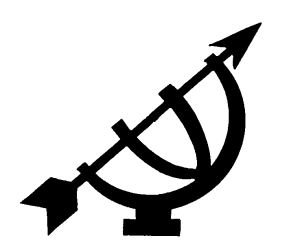

\title{
Wetenskap met en sonder diepte?
}

\author{
P.G.W. du Plessis \\ Sentrum vir Geloof en Wetenskap (emeritus) \\ Potchefstroomkampus \\ Noordwes-Universiteit \\ POTCHEFSTROOM \\ E-pos: pgwdup@yahoo.co.uk
}

\begin{abstract}
Science ... cannot even get off the ground without rooting itself in a kind of a priori 'faith' that the universe is a rationally ordered totality of things. Scientists always rely on a tacit faith (which they seldom reflect on in an explicitly conscious way) that there is a real world 'out there', that this real world hangs together intelligibly, that the human mind has the capacity to comprehend at least some of the world's intelligibility ... Without this kind of trust there could be no incentive to look for the order present in nature or to keep looking deeper into the specifics of this order
\end{abstract}

(Haught, 1995:23).

\section{Abstract}

\section{Science with and without depth?}

In trying to understand science in interaction with its presuppositions, values and bona fides, an overview of three different but closely related dimensions or layers or zones of science present in the functioning of different disciplines is given in this article. Then the different paradigms, presuppositions and/or control beliefs typical of modernist and postmodernist theories of science are underlined. This approach could contribute towards understanding some of the modernist and postmodernist affiliations and inclinations toward specific dimensions or particular phases of the scientific venture. In the critical evaluation of these schools of thought the concept "science" is understood as a multi-dimensional knowledge act. The history of science contains no traces of science without its creeds. It is, however, agreed that science is also underdetermined by its presuppositions and that it should not be equated to a world and life view. What science ultimately is and should be cannot be rationally and scientifically fathomed. Lastly it is attempted to explain in what way our view 
of wisdom as a deeper dimension of science also allows for a deeper (than logical) critical discussion with scientists holding a different view of the world.

\section{Opsomming}

\section{Wetenskap met en sonder diepte?}

In 'n poging om die wetenskap te verstaan in sy interaksie met sy vooronderstellings, waardes en bona fides word 'n oorsig gegee van drie verskillende maar verwante dimensies of lae of "sones" wat ons in die werking van talle vakwetenskappe aantref. Daarna word die verskillende paradigmas, vooronderstellings en/of tiperende bona fides van modernistiese en postmodernistiese teorieë belig. Hierdie benadering kan lig werp op genoemde denkskole se affiniteit vir of verbintenisse met een of ander spesifieke dimensie of fase in die wetenskaplike proses. In die kritiese kommentaar op hierdie denkskole word wetenskap verstaan as 'n meerdimensionele kennishandeling. In die wetenskapsgeskiedenis word nie spore van 'n gelooflose wetenskap gevind nie. Omdat wetenskap ook onderbepaal word deur sy vooronderstellings, is wetenskap nie gelyk aan 'n voorwetenskaplike lewens- en wêreldbeskouing nie. Wat wetenskap finaal is en behoort te wees, kan nie wetenskaplik en rasioneel deurgrond word nie. Laastens word gepoog om te verklaar in watter opsig ons siening van wysheid as 'n dieper dimensie van wetenskap ook ruimte laat vir kritiese (en meer as logiese) gesprekke met andersdenkende wetenskaplikes.

\section{Proloog}

Graag bring ek hulde aan die filosofiese denktrant van prof. Theo van der Merwe. Opvallend was sy vermoë om versoenende opmerkings te maak teenoor andersdenkendes. Tog het hy sy opmerkings en kommentaar gewoonlik afgerond met sagte kritiese vrae wat kern en bysaak duidelik wou maak.

Theo was 'n "medeklinker" in sy filosofiese gesprekke. Hy het graag ook by mede-Christendenkers (o.a. Augustinus, Vollenhoven, Stoker, Cherniss) stilgestaan en geluister. Sy ondersoekende intelligensie is gedra deur ' $n$ daadwerklike poging om simpatieke dialoog lewendig te probeer hou. Op die regte oomblik het hy met nederigheid sy verskil of sy instemming gemotiveer. Op 'n keer kon ek aan 'n buitelander vertel: "His service to the academic endeavour was to keep science faithful." 
Ons kan by dié denktrant aansluit, want ons sluit ook (grond-) motiewe, vooronderstellings en meta-kwessies in by die werking van wetenskappe. Wetenskap kan nie beoefen word sonder paradigmas, sonder bona fides of aannames, sonder voorveronderstellings nie. Wetenskap ontwikkel met en via vooronderstellings en denkraamwerke in verskeie "fases" of "sones". Wetenskap met "diepte" ontwikkel in daardie sones waar vooronderstellings en bona fides en aannames as regulerende oortuigings hul relatiewe stempel agterlaat op sowel die inhoud as die rigting van wetenskaplike ondersoek.

\subsection{Elke wetenskap het sy eie aannames waaraan "geglo" word}

In die loop van die artikel word gestel dat geloof nie slegs aanwesig is in ' $n$ Christelike benadering van die wetenskappe nie. Elke wetenskap sit vol van aannames waaraan geglo word. Ons kry nie 'n gelooflose wetenskap nie (vgl. onder andere Schuurman, 1998 en Van der Walt, 2002). Die een wetenskap verbied ons byvoorbeeld om te glo aan "die sterre vertel". Dieselfde wetenskap sê egter dat geloof aan "swart gate" baie "kosher" is, maar is sku vir die vraag "wat was vóór die oerknal?" So kan elke vakkundige die voorbeelde vermenigvuldig. Ons betoog dat die geskiedenis van elke wetenskap wemel van geloofsaannames, bona fides. In die artikel word dit kortliks geïllustreer deur te wys op die denkraamwerk en (soms versteekte) aannames en vooronderstellings van die positivisme/ empirisme/rasionalisme - en van 'n postmodernistiese denktrant oor die aard en werking van die wetenskappe.

Baie wetenskaplikes gee vandag toe dat verwondering en belange 'n noodsaaklike aanloop tot wetenskap vorm. Wetenskaplike kennis word ook inhoudelik bepaal deur nie-rasionele sake. Die misterie van die skepping (en ons nuuskierige verwondering daaroor) is tog ook ' $n$ bron van wetenskaplike kennis. Ons wetenskappe is in verskeie opsigte nie waardevry nie. Waardes speel 'n rol by die keuse van die onderwerp van ons navorsing. Die gevolge van ons ondersoek is op talle maniere van positiewe of negatiewe belang vir die samelewing. Ons wetenskap is self ' $n$ bepaalde waarde in ons kultuur. Alle wetenskappe is aan bepaalde norme en waardes onderworpe. 


\subsection{Drie vlakke of fases in wetenskapsbeoefening}

Daar kan breedweg drie vlakke of fases of lae of dieptes of dimensies in die wetenskap onderskei word.1

\section{- Die empiriese bolaag}

Gedurende die beginfase van enige vakdissipline (behalwe wiskunde?) is daar 'n empiriese stadium waartydens die versameling van gegewens die belangrikste wetenskaplike aktiwiteit is. Hierdie aktiwiteite word gewoonlik as die eerste of empiriese bolaag van wetenskapsbeoefening bestempel.

\section{- Middellaag: metodologiese en kennisteoretiese kwessies}

Versameling van gegewens en feite - soms ook data genoem - is op sigself egter nog nie "diep" of gegronde wetenskap nie. Feite en data moet geïnterpreteer word, dit wil sê daar moet vasgestel word wat die feite en data "vertel" oor die verskynsel of proses wat bestudeer word. Goeie wetenskaplike kennis mag sekerlik nie vassteek by blote beskrywing of empiriese ondersoek nie. Selfs die positivistiese wetenskaplike soek na meer - byvoorbeeld na die "sistematisering en klassifisering" van feite. Daar word gesoek na 'n teorie om verbande tussen feite te verklaar. Hierdie teoretiese raamwerk lê op 'n dieper vlak as die versameling van feite. Die middellaag van wetenskapsbeoefening hou sterk verband met metodologiese en kennisteoretiese kwessies.

Maar nie net die feite en data moet "geweeg" - dus geïnterpreteer word nie. Ook die verklarende teorie moet "geweeg" - dus geëvalueer word. Al maak Wolterstorff (1976:61) die lakoniese opmerking "those who work in the sciences spend relatively little of their time weighing theories ...", tog moedig hy vakwetenskaplikes aan om 'n "analysis of the weighing of theories" aan te pak.

\section{- Dieptelaag: grondoortuigings en paradigmavorming}

'n Fundamentele navorsingstaak van die hedendaagse universiteit is om nuwe denkstrategieë, paradigmas, selfs metodes en teorieë te ontwikkel en om bestaande kennis krities te evalueer. As elke vakspesialis maar net na die geskiedenis van haar/sy vak gaan kyk,

1 Laag, dimensie en diepte (selfs sone, horison of konteks) het as metafore/beelde ook elk hulle beperking aan duidelikheid. Tog help die metafore ons om beter te verstaan dat enige goeie wetenskaplike ondersoek 'n meervoudige komplekse aard ontwikkel wat empiriese en rasionele kennis oorstyg. 
sal sy/hy sien dat 'n mens se vak gemaak (en gebreek) word deur die gestoei tussen denkskole en paradigmas wat mekaar gereeld opvolg. Navorsing en skoling in die wetenskap behoort dus ook vas te stel watter paradigma 'n bepaalde wetenskaplike teorie ten grondslag lê.

Heelwat vakspesialiste is geneig om wetenskapsfilosofiese kwessies van hulle vakke na die filosowe te verwys. Self konsentreer hulle liefs op die "empiriese" en/of "metodologiese" vlakke - en laat die sogenaamde metafisiese vrae oor aan filosowe wat so graag spekuleer. Wetenskap word oppervlakkig bedryf indien ons die talle aannames, uitgangspunte en selfs doeleindes wil uitsluit van al die empiriese noterings en bewerkings en afleidings van feite. Wetenskaplikes wat byvoorbeeld uitsluitend in die kwantitatief-empiriese tradisie navorsing doen oor die mens en oor natuurverskynsels, stuur byna sonder uitsondering af op 'n eensydige (monistiese?) materialistiese en/of naturalistiese visie van mens en natuur.

Selfs een en dieselfde vakdissipline groei soms meer in die een laag/dimensie/fase as in die ander twee. Talle goeie wetenskappe bestaan uit al drie lae of fases of dimensies: kom ons noem dit kortweg 'n empiriese fase, 'n middellaag vol metodologiese kwessies en 'n voor-wetenskaplike dimensie van grondoortuigings wat 'n paradigma staande hou. ${ }^{2}$ As ons wetenskaplikes uitvra oor hulle "probleemstelling" of hulle "metodes" of hulle "veld van ondersoek" of hulle vooronderstellings - dan merk ons dat talle wetenskappe van hoë kwaliteit juis in meer as een fase (of laag) werksaam is. 'n Enkelsinnige, omvattende, logiese wetenskapsbegrip pas ook nie meer by sweetwarm wetenskapsbeoefening nie.

\subsection{Wat "wetenskap" behels, benader vanuit die dieptelaag}

Die sogenaamde dieptelaag veronderstel die ander dimensies van wetenskapsbeoefening. Anders gestel: die bolaag (oorwegend empiriese laag) en middellaag (primêr metodologiese dimensie) is verweef met die dieptelaag (paradigmas en bepalende bona fides). In goeie wetenskapsbeoefening loop die bolaag- en middellaag- oor in dieptelaagkwessies. Daarom verkies ons om die vraag "wat

2 Al het Kuhn se term paradigma spreekwoordelik dertien betekenisse, gebruik ons die term breedweg as die analitiese denkraamwerk van vooronderstellings, waardes en geloofsaannames waarbinne 'n groep wetenskaplikes hulle ondersoek doen. 
wetenskap is" eerder vanuit die dieptelaag (waarby die ander lae ingetrek is) te benader. Dit beteken dat ons wetenskap wil verstaan vanuit 'n kompleks van eiesoortige aktiwiteite, voorwaardes, van doelstellings, van relasies, van kontekste en van verantwoordelikhede.

Kortliks opgesom kom sommige van ons argumente neer op die volgende:

- dat wetenskap nie 'n eendimensionele aktiwiteit is nie;

- dat wetenskap in meer as een laag of sone werk (en behoort te werk);

- dat wetenskap nie kan (moet) stilstaan by feitekennis nie;

- dat wetenskap ook (moet) motiveer, evalueer, verstaan, kritiseer, simpatiseer;

- dat wetenskap meer is as logiese rasionaliteit;

- dat wetenskap waarde-afhanklik is;

- dat wetenskap van bona fides afhanklik is;

- dat kennis meer is as wetenskap(like kennis);

- dat wetenskap ook nie identies aan 'n lewens- en wêreldbeskouing is nie;

- dat wetenskap 'n wete met 'n gewete is (behoort te wees);

- dat wetenskap 'n strategie is om wysheid te bekom;

- dat wetenskaplike veritas nie sonder 'n etos van caritas kan bestaan nie;

- dat wetenskap daarmee tot 'n bedagsame seën vir die mensdom kan uitgroei;

- dat wetenskap wel uitgroei tot 'n komplekse en verantwoordelike menslike kenhandeling.

\section{Wetenskap met 'n empiriese bolaag}

Most of us would agree that the typically modernist view of science found its apex in the positivist view of science: here objective, true scientific knowledge is grounded in empirical facts which are uninterpreted, indubitable and fixed in meaning; theories are derived from these facts by induction or deduction 
and are accepted or rejected solely on their ability to survive objective experimentation; finally, science progresses by the gradual accumulation of facts (Van Huyssteen, 1998:14-15).

Woordvoerders van die Verligting (Aufklärung) en/of die modernisme stel onomwonde dat die strewe en soeke na waarheid die belangrikste taak van enige goeie wetenskap is. Daarom sal empiriste en positiviste graag klem lê op empiriese ondersoekmetodes om by die waarheid uit te kom.

'n Treffende voorbeeld van 'n positivisties-empiristiese wetenskapsopvatting vind ons in die statuut van die beroemde Britse Royal Society (in 1662 opgerig):

The business and design of the Royal Society is: To improve the knowledge of natural things, and all useful arts, manufactures, mechanick practices, engynes and inventions by experiments - (not meddling with divinity, metaphysics, morals, politicks, ...) (Aangehaal deur Doeser, 1985:34).

\subsection{Die positivisme}

\section{- Wetenskap as neutraal en sonder metafisiese dimensies}

Veral die positivisme het sterk daarop aangedring dat 'n skeiding gemaak word tussen die beskrywing van sake en die uitspreek van waardevoorkeure (of -afkeure), dat onderskei word tussen deskriptiewe en preskriptiewe uitsprake. Volgens die positivisme is wetenskaplike uitsprake beskrywend en universeel, terwyl waardeoordele voorskrywend en partikulier van opset is. Feite sê hoe sake is en waardes stel hoe sake behoort te wees. Feite is objektief vasstelbaar, waardes is subjektief. Feite is die werkterrein van die wetenskappe; waardes is die speelveld van ons praktiese lewe waar moraliteit en godsdiens voorsê wat goed en kwaad is. Wetenskaplike kennis maak waardes en geloof oorbodig - so sê die positiviste. Die positivisme was van oordeel dat wetenskap neutraal en sonder voorveronderstellings bedryf kan word; al wat moet gebeur is om die wetenskap te ontwikkel as 'n streng objektiewe metodologiese ontginning van probleme.

Auguste Comte word beskou as die vader van die positivisme. Volgens hom deurloop die mens se kennis van die werklikheid in fases:

- 'n teologiese fase waartydens verskynsels verklaar word met behulp van mites en godsdienstige geloof; 
- 'n metafisiese fase waartydens verskynsels verklaar word met behulp van idees en beginsels;

- 'n positiewe wetenskaplike fase waartydens verskynsels op grond van die positiewe waarneming van feite en met behulp van eksperimente verklaar (moet) word.

Volgens Comte groei egte wetenskap as dit homself bevry van teologiese geloof en metafisiese idees. Die positivisme bestry daardie fase van wetenskapsgeskiedenis waarin wetenskap 'n metafisiese of filosofiese dimensie sou hê. Daarmee wil positiviste die wetenskap ook bevry van die filosofie wat so graag besig bly met waardes en norme en die sin van die werklikheid.

Vir positiviste is wetenskap (moreel) waardevry, sentimentvry en vry van geloofsveronderstellings. Pasteur se pittige uitspraak was: die wetenskaplike mag 'n vaderland hê - maar die wetenskap het geen vaderland nie. Ander positiviste kon byvoeg: wetenskaplike kennis mag nie deur geslag of kultuur of bona fides (goedgelowigheid) besmet word nie.

\section{- Empiriese en rasionele wetenskappe moet slegs op feite en wetmatighede konsentreer}

Volgens empiriste en positiviste moet empiriese wetenskappe slegs op feite konsentreer en wetmatighede daaruit aflei sodat voorspellings gemaak kan word. Volgens empiriste en positiviste is geloof wetenskaplik irrelevant en onbewysbaar. In die woorde van Nobelpryswenner Sir Ernest Chain het wetenskap geen etiese kwaliteit nie en moet dit sigself beperk tot die beskrywing van natuurwette.

Gedurende die tyd van die Verligting was modernistiese stellings soos die volgende aan die orde van die dag: Alles wat werklik is, is redelik; alles wat redelik is, is werklik (Hegel). Die moed om jou eie rede te volg, self te dink, moed om die redelike te wil, is om outonoom denkend te wees (Kant). Die fondament van kennis lê nie in geloof nie, maar in die menslike rede en sy wetenskaplike denke.

Die positivisme en die gepaardgaande rasionalisme was van oordeel dat wetenskap neutraal en sonder voorveronderstellings bedryf kan word; al wat moet gebeur is om die wetenskap te ontwikkel as 'n streng objektiewe metodologiese ontginning van probleme. Vandaar die slagspreuk van die positiviste plus empiriste plus rasionaliste: "Wetenskap behoort neutraal te wees." In ons 
wetenskappe moet ons feite (dit wat is) en waardes (wat behoort te wees) van mekaar skei.

Die strewe is dat wetenskap antidogmatisties moet wees. Die wetenskap verklaar verskynsels rasioneel en in die proses van verklaring moet irrasionele raaisels, wonders, geloof, misteries en waardes opgelos en vernietig word - lui die meer aggressiewe gedagtegang van B.F. Skinner en sy groep. Die Wiener Kreis se manifes oor hul "wetenskaplike" beskouing van mens en wêreld soek op hulle beurt na 'n omvattende sisteem van konsepte:

Neatness and clarity of concepts are striven for, and dark distances and unfathomable depths rejected. In science there are no 'depths'; there is surface everywhere .... The scientific world-conception knows no unsolvable riddle (aangehaal deur Koningsveld, 1980:32).

\section{- Die neutraliteitspostulaat 'n gesigspunt sonder standpunt}

Intussen klink die oorbekende "facts are holy" na 'n positivistiese geloofsbelydenis (sic). Hierdie uitspraak is 'n selfweersprekende wetenskapsfilosofie van die positiviste. Die wetenskapsfilosoof Michael Polanyi stel byvoorbeeld dat "no truth is arrived at without the scientist assuming (or having faith in) a particular worldview. ... So the faith component, so important in religion, has its counterpart in science" (Stannard, 2000:170).

Met apologie aan Merleau-Ponty kan ons die kritiek van Christenwetenskaplikes so opsom: die neutraliteitspostulaat van die positiviste is 'n gesigspunt sonder standpunt (vue sans point de vue)!

Gestel jy beweer dat in jou vak al die teorieë op feite gebaseer is (behoort te wees). Dan kan 'n mens vra: Waarom moet 'n teorie op feite berus? Die standaard- positivisties/empiristiese antwoord daarop is: Ooreenstemming met feite is tog die maatstaf vir goeie of betroubare of ware wetenskaplike kennis. Maar daarmee sit ons met ten minste drie moeilike vrae: Wat is ooreenstemming - beteken dit gelyk aan - dus 'n replika van die feite? Vraag twee sal lui: Wat is 'n "feit"? Vraag drie is veral deur die hermeneutiese skool van Gadamer en andere geopper: Kan 'n feit buite 'n teorie of 'n konteks om bepaal en beskryf word? Die waarneming van feite vind tog nie onafhanklik van 'n probleemstelling plaas nie - ook nie onafhanklik van sosiokulturele kontekste nie. 


\subsection{Die modernisme}

\section{- Alles word gemeet aan rasionaliteit}

Rasionaliste en logiese positiviste besef dat die wetenskap van empiriese brood alleen nie kan leef nie en verkies liewer 'n logiese empirisme. Daarom word in aansluiting by ervaringsfeite klem gelê op rasionele betekenis en logiese afleidings. Om twyfel uit te skakel en om tot bewysbare waarheid te kom, is hipoteses en metodiese prosedures, en teorievorming juis die belangrikste komponente van wetenskap.

Die modernisme sien wetenskap as 'n rasionele drang om die werklikheid te beheers. Wetenskap wil 'n omvattende kennis van die werklikheid hê waardeur ons alles volledig kan verklaar en beheer. Die Verligting versinnebeeld die rasionele mondigheid van die mens teenoor die natuurmagte. ' $n$ Slagspreuk van die Verligting-denkers is immers: "Kennis is mag!" Dit is 'n kwessie van tyd, mannekrag en geld - dan is alle raaisels wetenskaplik opgelos. Die modernistiese mens ken en kán steeds meer. Die wetenskap van die modernisme wil verklaar hoe alles vanuit 'n chaotiese begin ordelik en redelik verloop het en redelik ontwikkel kan word en redelik verstaanbaar is. Die wetenskap van die modernisme word ook 'n tegnologiese mag waarvoor natuur en mens moet swig.

Alles - ook geloof - moet deur die tregter van rasionaliteit gaan alvorens dit (deur moderniste) as werklik, as waar, as goed aanvaar kan word. Goeie wetenskap word binne hierdie denkstroom verstaan as daardie wetenskap wat 'n dissiplinêre benadering met ingeboude gehaltekontrole en met 'n streng metodiese tug gebruik. Rasionaliste glo byvoorbeeld dat die weerlegging van die een teorie suiwer kan plaasvind op grond van logies-rasionele kritiek op die ander teorie en op grond van toetsing van die "wetenskaplike feite".

\section{- Religie van die outonomie van die wetenskap}

Die outonomie van die denke word as 'n geloofsartikel, as 'n voorwaarde vir suiwer wetenskaplike kennis gestel.

Hierdie outonomie van die wetenskap(like denke) is die afgelope eeu afwisselend versigtig en fel gekritiseer deur pragmatiste, eksistensialiste, hermeneutici, ook deur neo-Marxiste en Christenwetenskaplikes. Hart (1983:217) vat die wantroue in rasionaliteit as sleutel tot kennis soos volg saam: "There are suggestions today that the idea of the autonomy of reason, in spite of its implications for the rejection of faith, is itself held in faith." 
In ons wetenskaplike metodologie bestaan nie genoegsame skanse teen een of ander buitewetenskaplike waarde, belang of ideaal nie. Elke poging van die positivistiese wetenskap om hom daarvan te emansipeer, gryp juis terug op 'n buitewetenskaplike sentiment of veronderstelling of geloofsaanname.

Bostaande "neat image of science" wil wetenskaplike feite vry hou van subjektiewe waardes. Daarom mag die wetenskaplike met sy subjektiewe situasie en morele waardes nie as referensiepunt in ons wetenskapsbedrywigheid optree nie. Max Weber sê dat die wetenskaplike as gewone burger wel 'n mening mag hê oor morele en politieke sake

Nou is ons kritiese vraag aan "bolaag-wetenskaplikes": hoe los positiviste die probleem op as die mens in sy rol as burger teen besoedeling is, maar juis as wetenskaplike bydra tot daardie besoedeling?

\section{Bolaag-wetenskap - tog met 'n onderlaag?}

Die positivisme het meegebring dat baie vakwetenskappe 'n bloeitydperk beleef het met hul logies-empiriese ondersoeke. Bevry van metafisiese of filosofiese kwessies kon wetenskaplike kennis ontwikkel word. Beteken dit dat wetenskap dus sonder dieper metafisiese of filosofiese probleme beoefen kan (moet) word? Op hierdie vrae kom die insiggewende antwoord van Koningsveld (1980:23):

Het is echter van groot belang zich te realiseren, dat dit in hoge mate gevrijwaard zijn van filosofische problemen van de vakwetenschappen, alleen bestaat bij de gratie van het feit dat in een eerder stadium filosofische knopen zijn doorgehakt. Er zijn filosofische knopen doorgehakt met betrekking tot het kennisbegrip, de methode, het object en ook ten aanzien van de verhouding feit-waarde. Het doorhakken van deze knopen betekende steeds een bepaalde filosofische stellingname en deze filosofische stellingnames vormen nu de veelal onbewuste vooronderstellingen van de vakwetenschap.

Hipoteses en teorieë berus ook op sekere aannames wat die wetenskaplike maak (en moet maak) oor die aard van die verskynsel wat bestudeer word, oor die metode wat gevolg word, oor die plek en betekenis van sy ondersoek in die groter wêreld en oor die doel daarvan. "Suiwer" waarnemings word medebepaal deur ons metodes, ons teorie, ons werklikheidsbeskouing. Feite word geïdentifiseer binne 'n bepaalde lewensbeskoulike perspektief/ 
siening van dinge (Dooyeweerd, Wolterstorff) en binne bepaalde belange (neo-Marxiste) en binne sosiaal-historiese kontekste (Kuhn, Feyerabend). Nogeens: 'n teorie berus ook op sekere geloofwaardige of betroubare veronderstellings en aannames. Wetenskap is geen onafhanklike neutrale objektiewe, geloofslose, veronderstellingslose toegang tot die werklikheid en tot waarheid en geldige kennis nie.

\section{- Modernisme se voor-empiriese en voor-rasionele ideologie}

Moderniste soos ook positiviste, empiriste en rasionaliste wil die wetenskappe "ideologievry" hou. Maar as moderniste die wetenskappe beoefen en verstaan as die eksklusiewe toegang tot "waarheid" en tot "goedheid" in die menslike samelewing - dan het hulle wetenskap self ' $n$ ideologie geword. Meer nog: die positiviste hou nie by hulle eie opdrag om slegs die empiriese bolaag te ontgin nie. Hulle spreek wel 'n voor-empiriese voorkeur uit; hulle kom met 'n eis, 'n behoort, 'n voorwaarde: goeie wetenskap is wetenskap wat waardevry en sonder vooroordele behoort te wees. Die moraal van die positiviste eis dat alle wetenskaplikes hulle van enige moralisme moet weerhou.

Die Wiener Kreis se (positivistiese) wetenskapsbeoefening het as uiteindelike doel "die eenheid van die mensdom"; logiese rasionaliteit word die basis van (ware) wetenskaplike kennis én van die goeie samelewing. Vir neo-positiviste en kritiese rasionaliste bestaan daar “... een interne samenhang tussen wetenschappelijke en maatschappelijke vooruitgang en geldt de natuurwetenschappelijke methode als de hoogste belichaming van de menselijke rationaliteit" (vgl. Kunneman, 1987:137).

Daarom skryf die modernisme sy groot verhale in hoofletters: "Triomftog van die Rasionele Wetenskappe na Waarheid", "Die Westerse Industriële Rewolusie", "Die Groei en Bloei van Wetenskap en Tegnologie".

Modernisme beklemtoon, oorbeklemtoon en verabsoluteer die mag van die wetenskap - veral science wat verstaan word as "natuurwetenskap". Die modernis se kultuur is 'n wetenskapliktegnologiese kultuur. Tegnologie (veral as toegepaste wetenskap) het mag oor die praktyk van die menslike samelewing. Modernisme is 'n outoritêre denke wat wetenskap en tegnologie bo verdenking verklaar. Rasionaliste oordryf egter die rol van rasionele denke en plaas die beginpunt van wetenskap in die menslike rasionele denke self. 
Die selfversekerde ideaal van 'n suiwer wetenskap wat ons kennis moet uitbrei en onkunde moet bestry om 'n beter samelewing te skep, word deur Stannard (2000:161) soos volg beskryf:

One cannot help but be impressed by the pace of scientific advance and the way it is transforming our world through technology. Such successes have led certain scientists to adopt a triumphalist stance, claiming their science to be the only sure route to knowledge and understanding. According to this view known as 'scientism' - other modes of investigation (religion, for example) can be dismissed as unnecessary and irrelevant.

Volgens bostaande siening is rasionele kennis en sy tegnologiese instrumente gelyk aan mag oor die natuur en oor die mens. Die magtige wetenskaplike subjek (en sy instrumente) registreer en bereken en eksperimenteer, die tegnokrate meganiseer en industrialiseer en die samelewing verbruik. So ontstaan 'n kloof en vervreemding tussen subjek en objek.

Om die wetenskap so te bedryf dat dit hoofsaaklik 'n "meet-, weegen tel-aksie" van waargenome feite word, is 'n voorbeeld van 'n bolaag-wetenskapsbeoefening. Wie slegs dit wat getel, gemeet en geweeg kan word as "wetenskaplike waarheid" aanvaar, se eensydige en verkorte waarheidsbegrip sluit homself af van essensiële dele van die werklikheid. Selfs neo-positiviste begin dieper delf as die bolaag en moet toegee: wetenskaplike kennis is meer as sogenaamde empiriese kennis; dit is kennis gebou op "dieperliggende" metodologiese beginsels wat as norme geld. Op hierdie punt word die taak van die wetenskap die konstatering en analise van empiriese feite in ooreenstemming met metodologiese beginsels.

As en wanneer ons wetenskappe konsentreer op die dissiplinêre aard van ons vakgebied, delf ons dieper as die bolaag. Dan stel ons belang in die reëls vir "korrekte waarneming" of vir "logiese redenering" of vir "suksesvolle teorievorming" of reëls vir "goeie metodes". Kollegas wat hul vakgebied eerder vanuit die sogenaamde dissiplinêre aard daarvan wil beoefen, stel veral belang in die wetenskaplike metode wat ware kennis moet waarborg. So word wetenskap eerder as 'n modus operandus gedefinieer. Sulke kwessies vorm gewoonlik die tweede of teoretiese middellaag van die wetenskap.

Neo-positivisties gestel: Die metodologie is die sleutel tot hoëkwaliteit-navorsing en tot geldige kennisverwerwing. Die neopositivisme het uitgeblink in die definiëring van 'n universeel 
toepasbare (dus bruikbaar in natuur- en ander wetenskappe) rasionele prosedure om ware kennis te verwerf.

Volgens hierdie prosedure word die rasionele denke sy eie fondament. Die outonomie van die menslike denke staan voorop en is ' $n$ basis vir wetenskapsvorming en vir vooruitgang en geluk. Binne hierdie wetenskapsideaal kry ons 'n soort fundamentalisme: as die fondament rasioneel en empiries toetsbaar is, kan uit die grondbeginsels en empiriese wette tog vaste kennis afgelei word (deduktief en induktief). Wanneer ons klem lê op wetenskap as 'n sistematiese kenproses, op sistematiese ordening, op modelbou (ook op hipotesevorming en -toetsing) - om op sogenaamde wetenskaplike wyse 'n goeie teorie op te bou - dan is ons besig met 'n dieptelaag van wetenskapsbeoefening. Hierby moet ons bedink dat ons samehangende teorie 'n model skep van die deelwerklikheid wat ons bestudeer. ' $n$ Model is egter nie identies aan die werklikheid nie. Dit bly 'n teoretiese konstruksie.

Vir baie moderniste moet wetenskap geloof aanneemlik maak deur rasionele bewyse daarvoor te lewer. Die enigste ware/wetenskaplike kennis is feitekennis en rasioneel kontroleerbare waarheid. Wetenskaplike waarheid het universele en absolute aanspraak: vir alle tye en plekke; dit geld nie van private geloofsuitsprake nie.

Ook die rasionalisme kan nie bestaan sonder 'n geloofsoortuiging in verband met die sin van ons menslike lewe nie. Ernest Renan het dit pittig erken in sy Franstalige boek oor die toekoms van die wetenskap waarin hy sê: "My religie is die vooruitgang van die rede, dit wil sê van die wetenskap" (vgl. Charmet, 1946:15).

Teenoor die positivistiese denkskool se "view from nowhere"3 kan ons die verantwoordelikheid van die wetenskaplike as referensiepunt in ons wetenskapsbedrywigheid neem. Wetenskaplikes het 'n verantwoordelikheid om "goeie" wetenskap te beoefen. Voordat ons wetenskap beoefen, beskou ons die werklikheid as een samehangende geheel van ' $n$ verskeidenheid dinge. Die verskeidenheid van sake kan "beter" verstaan word indien ons ook 'n verskeidenheid metodes gebruik wat op die verskeidenheid sake toepaslik is (vgl. Stoker, 1965:66). Ons beste chemiese analises van die verf en doek van Rembrandt se beroemde skildery "Die nagwag" kan ons niks vertel van die estetiese eienskappe van die skildery nie. Ons wetenskaplike metodes in Chemie en in 'n vak soos 
Kunsgeskiedenis moet rekening hou met 'n komplekse werklikheid waarin 'n ryke, saamhangende verskeidenheid verskynsels aanwesig is.

Verskillende vooronderstellings van die neo-positiviste kom egter onder die kritiese spervuur van vakwetenskaplikes en van filosowe. Empiriste en rasionaliste se kenteoretiese voorkeur vir "waarnemingsuitsprake", hulle oordrewe klem op logika, hulle vereiste van 'n (rasionalistiese?) maatstaf vir kognitiewe betekenis, hulle eendimensionele siening van die groei van kennis - word verwerp of sterk gewysig deur postmoderne denkers en deur Christenwetenskaplikes (vgl. onder andere Rossouw, 1995 en Hart, 1983). 'n Kritiese herinterpretasie van die empiriese en logiese basis van die wetenskap is veral in die twintigste eeu voltrek: "Door het werk van Kuhn, Lakatos en Feyerabend is plausibel geworden dat waarnemingsuitspraken hun betekenis altijd ook ontlenen aan het theoretisch kader waarbinnen ze geformuleerd worden" (Kunneman, 1978:45).

\section{Watter laag ontgin die postmodernisme?}

Postmoderne denkers neem die fokus weg van wetenskaplike kennis en rig dit eerder op die sosiokulturele kontekste van die wetenskap. Vir postmoderniste is die sosiokulturele werklikheid belangriker as wetenskaplike kennis. Die sosiokulturele kontekste dien as sleutel en kader waarbinne wetenskaplike kennis verstaan moet word.

Postmodern science, ... finds its best expression in postpositivist, historicist ... philosophies of science, which have revealed the theory-ladenness of all data, and the shaping role of epistemic and non-epistemic value-judgments in the scientific process. Postmodern philosophy of science also reveals the narrative and hermeneutical dimension of science to us by acknowledging that science itself is a truly cultural and social phenomenon (Van Huyssteen, 1998:15).

Om 'n standpunt of ' $n$ beredenering of ' $n$ konklusie of ' $n$ bevinding of 'n waarneming in ons wetenskappe te motiveer, beteken veral om dieper te delf as die bolaag. Sodanige motivering veronderstel dat daar "iets dieper" agter die wetenskaplike bevindings en konklusies kan wees. Dit veronderstel ook dat daar iets dieper agter die wêreld, die mens en sy wetenskap is. Dit veronderstel dat (onbekende) motiewe ons kan help om wêreldgebeure of menslike gedrag of wetenskaplike metodes beter te verstaan. 
Maar gestel die werklikheid is die ene oppervlak sonder diepte? Dan sou net oppervlak bestaan. So redeneer baie hedendaagse filosowe en vakwetenskaplikes wat voorstanders is van 'n antimetafisiese benadering. Sodanige filosowe redeneer dat dit wat bestaan, dit is wat ons teenkom, wat ons beleef of wat onsself maak; 'n metafisiese werklikheid of God bestaan tog nie. Verder voer hulle aan dat ons moet ophou vra en soek na betekenis agter verskynsels of dieper as die ervaarbare werklikhede. Met hierdie gedagtes bevind postmoderne wetenskaplikes hulle ook in die geselskap van harde moderniste soos die positiviste van die negentiende en vroeë twintigste eeu.

Sowel moderniste as postmoderniste is aanhangers van sekularisering (en sekularisasie). Sekularisering beteken dat jy ook in die wetenskap moet afsien van enige bonatuurlike of boaardse beheer en verklaring van die natuur, van die mens en van die geskiedenis. Deurdat die postmodernisme afsien van die boaardse, die bonatuurlike, die metafisiese, skep dit ruimte vir 'n nuwe religie, wat slegs terugval op die natuur (naturalisme) en slegs op die mens (humanisme). Die mens se vryheid is nie meer gefundeer in God of in sy redelike wetenskap nie. Die mens mag maar enigiets doen en dit is nie belangrik of dit universeel reg of verkeerd is nie - solank die mens sy/haar vryheid van keuse volg of nie volg nie.

Vir die postmodernisme bestaan geen omvattende unitêre konteks om die natuur en die kultuur te interpreteer nie. Die wetenskap verloor sy onskuld, sy neutraliteit/objektiwiteit en kry 'n konteks, 'n relatiwiteit. Menslike kennis is kennis vanuit eindige, klein, privaat perspektiewe.

Die postmodernis glo nie meer in algemene beginsels of omvattende formules wat die hele lewe en die ganse werklikheid moet verklaar of verlos nie. Die postmodernisme se "einde van die groot verhale" beteken die einde van die Verligting (plus ateïsme) en van die Christendom (plus dogmatisme). "In a postmodern world, however, we worry about efforts to plan and build one world, one conversation for humankind, one story of humanity" (Van Huyssteen, 1998:22).

\section{- Kritiese gesprek met postmodernisme}

Die postmodernisme is 'n groot verhaal oor die verloop van ordelikheid na chaos, terwyl die modernisme se groot verhaal in verband staan met die ontwikkeling vanaf irrasionele chaos na 
rasionele ordelikheid. Elke indiwiduele verhaal is reg: anything goes! Pluralisme en relativisme is die wagwoorde.

Met reg kan gevra word: Geld die verhaal oor 'relativisme' ook vir die postmoderne denke self? Is relativisme en postmodernisme ook nie absoluut waar en universeel toepaslik nie? Relativisme ontneem homself die reg om ander standpunte (bv. 'n Christelike benadering in die wetenskap) te kritiseer as dit sy eie relativisme as algemeen geldig proklameer. As alle opvattings ewe waar/geldig sou wees, dan het 'n postmoderne relativis ook nie die reg om onverdraagsaam teenoor Christenwetenskaplikes te wees nie.

Met relativisme as leitmotief kom die volgende kritiese vraag na vore: Hoe is dialoog en kommunikasie in die wetenskap dan nog moontlik en hoe is 'n humane samelewing dan nog moontlik?

Wat dink ons van die postmodernisme se verwerping van die wetenskaplike pretensie van absoluutheid? Christenwetenskaplikes sê graag dat wetenskaplike kennis nie absoluut, algemeen geldig of bo-histories is nie - maar dat dit ook gebind is aan norme en waardes en kultuur-historiese kontekste én aan die (bo-rasionele) sin van die wetenskap. Christenwetenskaplikes beklemtoon die eindige, oop en voorlopige aard van wetenskaplike kennis. Christenwetenskaplikes sien graag af van die modernisme se ideaal van een wetenskaplike waarheid en die sogenaamde "Unity of Science". Ook ons wetenskappe is steeds onderworpe aan deurlopende hersienings.

Ons stem saam met postmoderne opmerkings dat geen groep wetenskaplikes die rasionele vermoë het om die werklikheid omvattend of genoegsaam of volledig of adekwaat te leer ken nie. Ons verskil van die postmodernisme se motivering dat die werklikheid (insluitende die kennende mens) basies irrasioneel, onlogies, relatief, diskontinu en chaoties van aard sou wees. Ons motivering verwys eerder na die komplekse verskeidenheid en samehang binne die skepping wat basies kreatuurlik, relasioneel, ordelik, a-rasioneel, vol wonderlike misteries is - en tog ook deels kenbaar, deels bewerkbaar is - in die woorde van Hermann (2000:170): "As we probe deeply into the universe, the more the mysteries multiply".

Soos die modernisme (en die ou Grieke), twyfel die postmodernisme aan alles. Anders as Descartes (vir baie die vader van die modernisme) twyfel postmoderniste ook daaraan of hulle aan alles twyfel. Dit is 'n omgekeerde skeptisisme wat moet terugval op 'n 
sekerheid - al is dit 'n negatiewe rasionele sekerheid. Hiermee presenteer die postmodernisme tog 'n negatiewe universele (wetenskaplike of menslike) waarheid! Is dit 'n klein persoonlike verhaaltjie waarvoor skelmpies algemene instemming opgeëis word? Sommige skrywers sê dat die postmodernisme nie net die teenpool van die modernisme is nie, maar ook die voltooiing daarvan is (vgl. Rossouw, 1995).

Die neo-Marxisme kom ook met 'n nuwe wetenskapsfilosofie en verwerp die positivisme se skeiding tussen die objek van ondersoek en die subjek van ondersoek. Selfs 'n vraelys veronderstel kommunikasie tussen subjek en objek. Die sosiale wetenskaplike moet die konsekwensies van die dialektiese verhouding met sy objek van ondersoek aanpak. Die sosiale wetenskaplike, die kultuurwetenskaplike, die geesteswetenskaplike is tog self deel van die werklikheid wat hy beskryf. Neutrale wetenskap is dus onmoontlik.

Die neo-Marxisme formuleer skerp aanklagte teen die modernisme waarin die volgende kritiekpunte voorkom: Kritiese wetenskappe moet ideologiekritiek beoefen; Die ideologie van die modernisme verdoesel die foute van tegnies-ekonomiese vooruitgang; Tegniesekonomiese vooruitgang beteken nie noodwendig praktiese-sedelike vooruitgang of prakties-vrye kommunikatiewe handelinge nie; Ideologiekritiek - in plaas van die sogenaamde logies-empiriese metode - is die ideale metode om verandering en bevryding te bewerk.

Jürgen Habermas en andere wil 'n emansipering vir mens en samelewing bepleit en die mens selfs bevry deur middel van 'n andersoortige wetenskapsopvatting en 'n ander wetenskapspraktyk (of metodologie) (vgl Klapwijk, 1976). Maar hiermee is die groot meta-narratief van die neo-Marxisme geformuleer: Daar is geen wetenskap sonder sy kwota voor-onderstellings en voor-waardes nie.

Christenwetenskaplikes erken dat selfs die jongste wetenskaplike kennis en die fynste tegnologie ook maar feilbare produkte van mense is; tog is dit nie waardeloos nie. Die waarde en kwaliteit daarvan kan en moet egter deurlopend aan allerlei norme getoets word, en die norme is baie meer as slegs die logiese norme van rasionele beredenering. Die logies-wetenskaplike norme (behoort) hand aan hand te gaan met etiese, kulturele, historiese en juridiese norme. Susan VanZanten-Gallagher (1997:161) som 'n kritiese gesprek met die postmodernisme so op: 
... Christians will part with postmodernists who hold that the only reality is that constructed by human beings, that all rationality is completely flawed, and in the practice of scholarship, we should merely celebrate ourselves.

\section{Wetenskap: wysheid in diens van caritas}

As ons die wetenskap benader en beoefen as kennis wat verantwoord moet word, as kennis wat dinamies, nuttig en betreklik is, maar nie allesomvattend is nie - dan sien ons wetenskap as 'n strategie om wysheid te bekom. Wysheid beteken die insig om die betekenis van ons kennis tot seën en voordeel van mens en wêreld te versprei. Wysheid beteken veral om te weet wat om te doen. Dit beteken ook dat ons toepaslike norme vir ons probleme sal aanvaar.

Enige wetenskap het 'n dieptelaag; sommige wetenskapsfilosowe noem dit ' $n$ metateoretiese laag. Ons loop hierdie dieptelaag raak in die paradigma(s) (teoretiese denkraamwerk plus voor-teoretiese aannames) wat eie is aan elke vakwetenskap. Waar ons veral die aannames en die veronderstellings wat die wetenskaplike oor sy studieveld en sy metodes maak, bestudeer en krities beoordeel, daar word 'n dieper laag van die wetenskap ontgin. Hierdie dieptelaag van die wetenskap kan as 'n aktiewe deel van wetenskapsbeoefening beskou word.

\section{- Simbiose tussen vakkennis en grondslaestudies}

Die verantwoordelike wetenskaplike se spesialiskennis is (behoort) nie geamputeer (te wees) van grondslaekennis nie. Wetenskapsbeoefening is ' $n$ simbiose tussen vakkennis en grondslaestudies. Anders gestel: Die simbiose tussen vakkennis en grondslaestudies gee geboorte aan nuwe insig en wysheid. Grondslaestudies help wetenskaplikes ook om 'n beter idee van die inherente niebewysbare, nie-rasionele basis en waardes van hulle wetenskappe te kry. Hulle verantwoordelikheid in die wetenskap word deur Christenwetenskaplikes deel gemaak van die omskrywing en beoefening van "wetenskap". Daarom impliseer en beteken wetenskap dikwels 'n spesifieke etos. Wetenskap is 'n wete met 'n verantwoordelike gewete.

De richting die het Westerse wetenschappelijke denken in het verleden is ingeslagen heeft zijn neerslag op de mens en op de samenleving niet gemist. Groeipsychoses, mislukte stedebouw, milieuvervuiling, congestie, snelle energie-uitputting: het zijn allemaal symptomen van gekozen richtingen die niet tot een goed resultaat leidden. In meer ethische zin kan men stellen dat 
het ontbreken van een verantwoord normatief kader voor het toekomstdenken een ernstige zaak is: immers, niet alles wat technisch en wetenschappelijk mogelijk is, is ethisch geoorloofd (Nijkamp, 1980:249).

Die studie van die dieptelaagprobleme van 'n vakgebied staan (ouderwets?) bekend as grondslaestudies. Grondslaestudies is nie 'n soort fundamentalisme nie. Grondslaestudies gee rekenskap van die beoefening van wetenskap. Sodra ons rekenskap egter 'n beroep op rasioneel universeel aanvaarbare evidensies word, verval dit in fundamentalisme. Waar ' $n$ vakwetenskaplike die moed het om te vra na die voorveronderstellings, kontekste en grense van sy vakwetenskaplike kennis, kry ons 'n vak-filosofiese studie van die "context of discovery". Grondslaestudies het alles te make met 'n kritiese ingesteldheid teenoor die eie vak se denkskole en gepaardgaande bona fides. Grondslaestudies en die vakfilosofie daarin is inherent 'n dieptelaag van enige wetenskapsbeoefening.

\section{- Ontginning van metateoretiese kontekste}

Ontginning van die metateoretiese kontekste van enige wetenskap help om eensydigheid en reduksionisme in spesialisering teen te werk. Daarmee verkry ons 'n beter verstaan van die plek van die wetenskap in die menslike kultuur; daarmee kry ons hopelik ook 'n beter insig in samelewingsprobleme met die oog op die broodnodige beskeie diensbare leierskap wat ons as wetenskaplikes moet bied. Wysheid help ons om nie iets kreatuurliks te verabsoluteer nie. Dan vermy ons reduksionisme en kry ons wetenskaplike insig in die verskeidenheid van die skepping tesame met die samehang van daardie verskeidenheid. Antimetafisiese gedagtes wat gekant is teen alles wat nie fisies van aard is nie - erken eintlik slegs 'n eendimensionele werklikheid waarbinne 'n verskeidenheid bestaanswyses sou verdwyn.

Voorwetenskaplike veronderstellings berus nie op 'n empiriese waarnemingsbasis nie; ook kan dit nie gerasionaliseer word nie. Veronderstellings funksioneer veral as waardegelaaide kennisinstrumente wat ons hipotese en ons teorievorming medebepaal. Wetenskap beteken meer as die enumerasie van empiriese feite; wetenskap beteken meer as 'n sisteem van logiese beredenerings. Kennis het meer as net 'n logies-wetenskaplike kant; kennis het ook 'n sosiokulturele en 'n morele dimensie. Hart (1983:221) wys byvoorbeeld op die veelkantigheid van rasionaliteit: "Rationality is a dimension of all knowing, but not all knowing is rationally dominated. 
... typical rational processes such as reasoning or arguing ... do not occur only in science ..."

\section{- Wetenskap as strategie om wysheid te bekom}

Die stelling dat wetenskap 'n strategie is om wysheid te bekom (in plaas van om byvoorbeeld mag te bekom) berus op die opvatting dat menslike redelikheid en wetenskaplike rasionaliteit spesifieke grense en afhanklikheidrelasies het, onderhewig is aan toepaslike norme en ook gekoppel is aan bedagsame diens en caritas. Wetenskap as strategie (om wysheid te bekom) wil juis ook rekenskap gee van die voorwaardes, die voorteoretiese veronderstellings van talle kontekste en van die teoretiese paradigmas waarbinne wetenskapsbeoefening algaande moontlik is.

Vir Nijkamp (1980:248) sou dit onwys wees om uit reaksie teen die wetenskap se humanistiese vooruitgangs- en magstrewe ook alle aansprake en prestasies van die wetenskap af te wys. Wetenskap kry tog 'n relatiewe betekenis teen die agtergrond

... van de universele ambtsopdracht om de aarde op verantwoorde wijze te ontplooien, d.i. ter ere van God en tot heil van de naaste. In dit historisch proces van cultuurontsluiting is aan het wetenschappelijk denken de plaats toebedeeld om door middel van analytische aanpak meer inzicht te krijgen in de structuur en de ontwikkeling van de geschapen werkelijkheid.

Saam met Seerveld (se advies aan studente) kan ons wetenskapsbeoefening verbind aan verwondering, groeiende begrip en diensbare insig (of caritas):

During your time in higher education, some reality of God's world fascinates you, and now you have the opening to spend time in probing, examining, researching, practising, and testing your growing understanding of whatever this wonder be in all its marvellous interconnected richness until you gain the beginnings of 'serviceable insight' (Seerveld, 2002:12).

\section{- Wetenskaplike kennis moet deurlopend hersien word}

Die mens moet sy wetenskaplike kennis deurlopend hersien. Geen wetenskaplike het algehele insig in alle dinge nie. Alleen God ken die dinge soos hulle is. Mense ken ten dele. Mense is op weg na waarheid; mense streef na betroubare kennis. Waarheid kry 'n eskatologiese betekenis wanneer die mens en die res van die skepping ten volle geken sal word. Selfs Christus het sy leer nie as 'n geordende sisteem in tydlose begrippe aangebied nie. Hy leer 
ons in gelykenisse en met wonderwerke. Geloof in God is nie dieselfde as die opsê van teoretiese leerstellings oor God nie. Daarom moet die mens sy verstaan en sy formulering van Christus se leer en lewe steeds kan hersien en reformeer.

Ons kan nie alle feite en alle fasette van die werklikheid wetenskaplik beskryf en analiseer nie. Elke wetenskap is maar 'n soort padkaart wat baie feite weglaat en sekere feite selekteer. Elke wetenskap selekteer 'n probleem, selekteer 'n metode(s), selekteer 'n hipotese, selekteer 'n teorie, selekteer 'n toepassingsveld.

Henk Geertsema verwerp die ideaal van absolute rasionele kennis. Die ideaal is fundamenteel onbereikbaar, vanweë die kreatuurlike grense van menslike kennis:

The rationality of science is a human rationality, not an absolute one, as Greek philosophers and many other philosophers in their footsteps have mistakenly thought. ... Clearly, knowledge obtained through defined concepts and logical rules opens up reality to deeper insights in a certain way. But this does not mean that reality is thereby revealed in its true form. ... Reality is more than rational" (Vgl. Van der Meer, 1996:304-305).

\section{- Wetenskap ook verbind aan nie-rasionele sake}

$\mathrm{Al}$ is wetenskap 'n rasioneel gekwalifiseerde saak, is dit onlosmaaklik verbind aan talle nie-rasionele sake. Wetenskaplike kennis ontstaan nie los van 'n relasie tot nie-rasionele sake nie. Nog sterker gestel: Ons teoretiese rasionele kennis kan nie sonder voorteoretiese kennis en waardekeuses funksioneer nie. Bona fides is nie "suiwer wetenskaplike" kennis nie; dit is oortuigings wat religieus, histories, sosiokultureel van aard kan wees en wat saamhang met die diepste oortuigings wat die wetenskaplike huldig oor die oorsprong, samehang en sin van die wêreld. Bona fides kan ook saamhang met kernbelange van groepe in die samelewing. Die verbintenis aan sekere bona fides en waardes is 'n onvermydelike voorwaarde vir ons wetenskaplike navorsing. Let op die goeie suggesties van Eliot (1999:73) as hy digterlik vra na die sin van lewe, kennis en inligting:

Where is the Life we have lost in living?

Where is the wisdom we have lost in knowledge?

Where is the knowledge we have lost in information?

('The Rock') 


\section{- Die ideaal van 'n caritas-wetenskap}

Die natuur, die lewe en die samelewing gaan immers aan wetenskaplike inligting en informasie vooraf. Wetenskaplike kennis kom agterna - soos woordeboeke agter die taal aanloop. Daarom sal ons wetenskaplike teorieë uiteindelik ook rekening moet hou met ons voorwetenskaplike lewens- en wêreldbeskouing.

Solank moderniste vas glo4 aan die onafhanklikheid van wetenskaplike denke, solank postmoderniste vas glo aan die willekeurige keusevryheid van die mens - solank word wysheid gesoek in 'n relatiewe denke en 'n afhanklike vryheid. Christenwetenskaplikes soek wysheid in caritas-diens.

Daarom sal ons die betekenis van ons wetenskaplike insigte moet aantoon vir die samelewing waarin ons funksioneer. Ons moet streef na 'n wetenskap in diens van God en tot seën van die naaste wetenskap wat vry is om caritas-diens te lewer. Kennis hoef ons nie altyd in staat te stel tot beheersing van sake nie. Kennis en gepaardgaande wysheid moet ons uiteindelik help om versorging en caritas te verskaf. Venter (1997:464) se voorstel insake 'n "caritaswetenskap" gaan ook oor die sin van ons wetenskappe en is in hierdie opsig vanpas: "Caritas is omvattend - dit is ' $n$ verhouding van beskerming, herwinning, ontsluiting en waardigmaking; en die ander nie in die steek laat nie."

Ons moet die wetenskaplike as "beter-weter" vermy. Beskeidenheid en bedagsaamheid word ' $n$ waardevolle en praktiese eienskap van groot wetenskaplikes as hulle deur middel van hul kundigheid 'n lewe van diens en caritas veral aan die naaste nastreef. Wetenskap het nie slegs met logiese waarheid te make nie; wetenskap het ook te make met etiese goedheid - met bedagsame verantwoordelikheid en bedagsame caritas.

The word 'thoughtfulness' conveys ...

both the notion of being filled with reflections about important matters of human concern and the notion of being considerate for others.

The same double meaning applies to the corresponding vice:

to be thoughtless is to be both foolish and inconsiderate (Schwehn, 2002:57). 


\section{Op soek na dieper kritiese gesprekke in ons wetenskappe}

'n Kritiese ingesteldheid teenoor die eie vak se (meestal implisiete) veronderstellings, sy paradigmas en sy metodes van kennisverwerwing, van kennistoetsing en van teoriebou stel wetenskaplikes in staat om dieper te delf as 'n empiriese ondersoek. Om rekenskap te gee van wetenskapsbeoefening en van die kontekste en grense van wetenskaplike kennis is 'n onvermydelike studie van "grondslae". Ook dit vorm 'n filosofiese dieptelaag of die "context of justification" van hul wetenskap. Die "context of justification" (die nadenke oor en verduideliking van die verloop van 'n wetenskaplike ondersoek) is wesenlik deel van die geskiedenis van elke wetenskap (of die "context of discovery").

\section{- Immanente kritiek}

Thomas Kuhn (1970) toon in sy boek oor die struktuur van wetenskaplike revolusies aan dat daar nie voldoende gemeenskaplike rasionele kriteria bestaan waarvolgens verskillende denkskole mekaar logies kan oortuig nie. Logiese redes is nooit voldoende om ' $n$ verwerping van een paradigma en die aanvaarding van 'n ander paradigma te motiveer nie. Daarom stel ons voor dat kritiese debatte die onvoldoende gemeenskaplike logiese kriteria benut. Dit is tog 'n vorm van immanente kritiek.

Sodoende kan die kritiese debat met andersdenkendes goedskiks begin met kritiek op die sogenaamde empiries-rasionele vlak. Dit kan immanente kritiek genoem word. Hier vra ons dikwels na die "logika" van 'n teorie. Ons kritiese gesprek met ander konsentreer dan op logiese konsekwentheid. Wetenskaplike A kan ook kontroleer of $B$ miskien onlogiese afleidings gemaak het en $B$ kan kontroleer of A meer as een betekenis heg aan dieselfde begrip. In hierdie opsig kan 'n mens ook selfkritiek toepas deur te vra of daar logiese konsekwentheid in jou eie wetenskapsbevindings en beredenerings is. Miskien is daar weersprekings in my teorie. Ook kan gevra word: Is die teorie 'n samehangende sisteem - of is die konklusie dalk 'n sirkelredenasie?

Die verantwoordelike wetenskaplike is bereid om sy metodes, sy dataversameling, sy probleemformulering, sy antwoorde, ensovoorts te laat toets en evalueer deur medewetenskaplikes. Dit maak kommunikasie, dialoog en kritiese evaluering tussen wetenskaplikes 'n lewensaar van wetenskaplike kennis. Die wetenskaplike soek wel na intersubjektiewe geldigheid en antwoorde. 


\section{- Transendente kritiek}

Meestal kry gespreksgenote groter duidelikheid as hulle transendente kritiek op mekaar se standpunte uitoefen. Dan word veral op verskille gelet. Daar word dan in wese eintlik saamgestem oor verskille! Maar ons kan verder as om te "agree to differ". Gestel ons nooi verskillende vakwetenskaplikes om vanuit hulle studievelde lig te werp op 'n gemeenskaplike probleem (byvoorbeeld omgewingsbesoedeling) - kan ons praat van 'n multi-dissiplinêre aanpak. Dit bly 'n beperking van so 'n gesprek tussen vakwetenskaplikes: Die verslag sal neig na 'n opeenstapeling van hoofsaaklik losstaande inligting en die integrasie van kennis sal bly vassteek by die gemeenskaplike probleem.

Die poging om 'n gesamentlike verslag van al die deel-antwoorde op te stel, roep al na 'n inter-dissiplinêre samewerking. Soms word die deel-antwoorde tot 'n gemeenskaplike antwoord opgesom deur dit tot 'n statistiese raamwerk te reduseer of te vertaal. Dit kan ook as die begin van ' $n$ sydige interdissiplinêre gesprek gesien word met die statistikus as voorsitter. Daarom behoort die deel-antwoorde ook vanuit die studieveld en dissiplinêre matriks van elke ander wetenskap opgesom/vertaal te word. Dit skep tog geleentheid om ook te soek na saakmakende verskille en moontlike gemeenskaplikhede.

\section{- Transendentale kritiek}

Kritiese gesprekke kan verder vorder as immanente en transendente kritiek. Dikwels vra ons na dieper redes en begronding. Op grond waarvan sê A sus en B so? Wat is hulle uiteindelike begronding; waarop grond hulle die redes; watter voorveronderstellings huldig hulle? Transendentale kritiek (ook grenskritiek genoem) vra na gronde, grense, voorwaardes, aannames, bona fides en kontekste in die wetenskap. Transendentale kritiek probeer delf na die diepste oortuigings of die laaste gronde wat wetenskaplikes aanbied vir hulle beskouings. Kritiek is ook 'n uitsif van en soeke na daardie bona fides waarvoor geen verdere redes aangegee kan word nie. Gesprek en samewerking met andersdenkendes beteken dan om aan medewetenskaplikes antwoorde te gee in verband met jou feite en waardes, jou metodevoorkeur en relevante vooronderstellings, jou bona fides.

\section{- Ekshaeretiese kritiek: waarheidselemente in ander stelsels}

Om op ooreenkomste te let, is ook 'n vorm van kritiek. H.G. Stoker praat van ekshaeretiese kritiek wat let op "waarheidselemente" in 
ander stelsels. Jaap Klapwijk wil ook die waarheidselemente van andersdenkendes losmaak van hul ideologiese konneksies en dit sodoende transformeer (vgl. Klapwijk aangehaal in Hart, 1983:109). So byvoorbeeld het die materialisme geldige punte as gestel word dat "materie bestaan" en dat "alles van materie afhanklik is". Die skepping bestaan inderdaad uit "baie fisiese of stoflike" dinge; en die res van die skepping is op verskeie manier daarvan afhanklik. Maar sodra die materialisme sy grondoortuiging uitspreek dat "net materie bestaan" en "alles" eintlik net een of ander vorm van fisies-chemiese prosesse sou wees - dan word die skeppingsverskeidenheid gereduseer tot enkel fisiese dinge. Dit is 'n verabsolutering van materie. Materie word sodoende tot 'n alfa en omega verklaar - iets wat volledig op sigself sou kon staan en aan alle ander dinge sin en doel sou kon gee.

\section{- Grondslaekwessies bestaan in alle studierigtings}

Grondslaekwessies bestaan in alle fakulteite en studierigtings. Dit is onder andere teenwoordig in ons siening oor die aard en grense van wetenskap en sy metodes; oor die plek van die wetenskappe in die menslike samelewing en kultuur; oor die verhouding tussen teorie en praktyk, tussen wetenskap en sy basiese aannames, vooronderstellings, aksiomas, oor die verhouding tussen lewensbeskouing en wetenskap, tussen geloof en wetenskap. Grondslaekwessies is ook aanwesig in die wetenskaplike se openlike verklaring in verband met die "basiese grondstof" waaruit mens/samelewing en wêreld/natuur sou bestaan - vergelyk byvoorbeeld die materialisme se geloof soos vroeër in die artikel bespreek.

\section{- Wetenskap kan die werklikheid nie omvattend ken nie}

'n Belangrike beperking van enige wetenskap is dat dit ons slegs een soort kennis (teoretiese kennis) kan verskaf; wetenskap kan byvoorbeeld nie die sin van die lewe (en van die wetenskap) verklaar nie. Ons wetenskaplike kennis is geen duplikaat van die werklikheid nie. Ons wetenskaplike kennis toon altyd 'n tekort. In ons wetenskaplike dissiplines kan ons nie die volle werklikheid omvattend ken nie. Die skepping is ten diepste 'n geheim. Hierdie geheim veroorsaak dat wetenskaplike kennis bepaald, beperk, betreklik, voorlopig en oop is. Tereg sê George Ellis (2000:165): "Science cannot tell you why the universe exists. And above all it cannot tell you whether or not God exists." 


\section{- Die ontginning van uitgangspunte maak 'n oop gesprek moontlik}

Die ontginning van die kontekste van enige wetenskap help om eensydigheid en reduksionisme in spesialisering teen te werk. As ons die antwoorde van ons eie vakgebied kan relativeer en in konteks kan beoordeel, dan stel ons onsself oop vir insigte deur ander wetenskaplikes met ander raamwerke. So begin ons wetenskap al hoe meer op 'n trans-dissiplinêre wyse beoefen. Die eie studieterrein, die eie metodiese styl, die eie kognitiewe sisteem van ons vakbeoefening word nie daardeur opgehef nie; dit word eerder deur die betrokke kontekste verryk, verdiep en gerelativeer. Ten slotte: wetenskap word deur konkreet lewende mense gemaak - nie deur 'n rasionaliteit of swewende rede nie.

Saam met Jan Hoogland (2005:39) kan ons stel dat deur wedersydse erkenning van die eie vooronderstellings 'n oop gesprek tog moontlik gemaak word:

... wie zich eenmaal openstelt voor de uitgangspunten van de eigen manier van denken, creëert daarmee ruimte zich tot die uitgangspunten te verhouden en er niet langer alleen maar de gevangene van te zijn.

\section{- Wetenskap is nie eendimensioneel nie}

Al sou ons andersdenkendes graag as ketters afmaak, kan kritiese debat ook op basis van die verskillende paradigmas en gepaardgaande bona fides plaasvind. Hoe so? Al is wetenskap "vol" bona fides, dit is nog geen absolute kennis nie. Ja, wetenskap is "onderbepaald" deur feite, maar wetenskap is ook onderbepaald deur geloof. Wetenskap bestaan nie van A tot $Z$ net uit vooronderstellings en geloofskennis nie. Wetenskap is nie identies aan voorwetenskaplike lewens- en wêreldbeskouing nie. In 'n ander verband is dit so gestel: "Wetenskap kan geloof nie monopoliseer nie. Maar geloof kan wetenskap ook nie monopoliseer nie. Wetenskap en geloof kan mekaar nie volledig distribueer of uitput nie" (Du Plessis, 1983:2).

Wetenskap is nie eendimensioneel nie - dit is 'n kompleks van (minstens?) drie kennisdimensies. Wetenskap is 'n unieke interaksie tussen teoretiese nadenke en sy paradigmatiese konteks; wetenskap is ook voorlopige resultaat van die samespel. Anders gestel: wetenskap word onderbepaal deur feite én waardes, ervaring én denke, logiese beredenerings én vooronderstellings. Wat 
wetenskap finaal is/behoort te wees, kan ons nie wetenskaplik en rasioneel deurgrond nie.

\section{Geraadpleegde bronne}

CHARMET, R. 1946. De toekomst der wetenschap. 's-Gravenhage: Stols.

DOESER, M.C. 1985. Waar is wetenschap goed voor? Over wetenschap en ethiek. Kampen: Kok.

DU PLESSIS, P.G.W. 1983. 'n Opdrag en 'n vinding in Stoker se wetenskapsleer. Reeks J. Potchefstroomse Studies in Christelike wetenskap: Studiestuk no. 6. Potchefstroom: PU vir $\mathrm{CHO}$.

ELIOT, T.S. 1999. The wast land and other poems. London: Faber \& Faber.

ELLIS, G. 2000. Are there limitations to science? (In Stannard, R., ed. God for the 21st century. Philadelphia: Templeton Foundation Press. p. 163-165.)

HART, H. et al., ed. 1983. Rationality in the Calvinian tradition. Lanham: University Press of America.

HAUGHT, J.F. 1995. Science and religion: from conflict to conversation. New York: Paulist Press.

HERMANN, R. 2000. Science and religion: converging paths to truth. (In Stannard, R., ed. God for the 21st century. Philadelphia: Templeton Foundation. p. 169-171.)

HOOGLAND, J. 2005. Reformatorische wijsbegeerte in het gedrang. Beweging, 69(4):33-42.

KLAPWIJK, J. 1976. Dialektiek der Verlichting. Amsterdam: Gorcum.

KONINGSVELD, H. 1980. Het verschijnsel wetenchap. Amsterdam: Boom.

KUHN, T. 1970. The structure of scientific revolutions. Chicago: University of Chicago Press.

KUNNEMAN, H., red. 1987. Wetenschap en ideologiekritiek. Amsterdam: Boom.

LOTTER, H. 1995. Postmodernism and our understanding of science. (In Rossouw, G.J., ed. Life in a postmodern culture. Pretora: HSRC. p. 5169.)

NAGEL, T. 1986. The view from nowhere. New York: Oxford University Press.

NIJKAMP, P. 1980. Herfstij der vooruitgang. Groningen: De Vuurbaak.

ROSSOUW, G.J., ed: 1995: Life in a postmodern culture. Pretora: HSRC.

SCHUURMAN, E. 1998. Geloven in wetenschap en techniek. Amsterdam: Buijten \& Schipperheijn.

SCHWEHN, M.R. 2002. Where are the universities of tomorrow? (In Sterk, A., ed. Religion, scholarship and higher education. Notre Dame: University of Notre Dame Press. p. 50-59.)

SEERVELD, C. 2002. Reformational Christian philosophy and Christian college education. Pro Rege, 30(3):1-16.

STANNARD, R., ed. 2000. God for the 21st century. Philadelphia: Templeton Foundation.

STOKER, H.G. 1965: Outlines of a deontology of scientific method. (In De Gaay Fortman, W.F. Philosophy and Christianity. Kampen: Kok. p. 57-77.)

VAN DER MEER, J.M., ed. 1996. Facets of faith and science. Vol. 4. New York: University Press of America.

VAN DER WALT, J.L. 2002. Scholarship in a changing intellectual climate. Potchefstroom: Centre for Faith and Scholarship, PU for CHE. 
VAN HUYSSTEEN, J.W. 1998. Duet or duel? Theology and science in a postmodern world. London: SCM.

VAN RIESSEN, H.1962. Filosofie en wijsheid. Delft: Waltman.

VANZANTEN-GALLAGHER, S. 1997. Faith, scholarship and postmodernism. Koers, 62(2):149-162.

VENTER, J.J. 1997. Filosofie en universitêre wetenskapsbeleid: Caritas, sapienta, scientia. Koers, 62(4):447-473.

WOLTERSTORFF, N. 1976. Reason within the bounds of religion. Grand Rapids: Eerdmans.

\section{Kernbegrippe:}

grondslaekwessies

modernisme, postmodernisme, positivisme en rasionalisme:

paradigmas en vooronderstellings

wetenskap as beperkte multidimensionele kennishandeling

wetenskaplikheid: voorveronderstellings, bona fides, waardes vir wetenskapsbeoefening: sones/fases/dieptelaag

wetenskapsfilosofie

\section{Key concepts:}

foundational issues

modernism, postmodernism, positivism, rationalism: paradigms and presuppositions

philosophy of science

science: preconditions, bona fides, values for

science as limited multilayered knowledge act

scientific practice: zones/phases/layers 
